\title{
Preparation of briquette coal with a lubricating oil sludge as binder
}

\author{
Tonghuan Zhang',a, Xin Chen ${ }^{2, b}$, Xi Zhao ${ }^{3, c}$, Yingjie Gao ${ }^{4, d}$, Yanwei Song,e \\ ${ }^{1}$ College of Chemical and Environmental Engineering, Shandong University of Science and \\ Technology, Qingdao, 266590, CHINA
}

axiyue198751@126.com,b1154258469@qq.com,,249716293@qq.com, ${ }^{\mathrm{d} 1271519338 @ q q . c o m}$

Keywords: briquette, binder, lubricating oil sludge

Abstract: The lubricating oil sludge from steel wire drawing factory contains organic compounds mainly of fatty acids, which has good binding property and combustion performance. In this paper, briquette is prepared from pulverized coal with this industrial sludge as binder. The viscosity of sludge was tested to be $2.44 \mathrm{~Pa} \cdot \mathrm{s}$. The effects of sludge content, forming pressure and drying time were studied by single factor test. The falling strength of briquette was increased first and then decreased with the increase of forming pressure from $6 \mathrm{MPa}$ to $14 \mathrm{MPa}$, and the suitable forming pressure was determined to be $12 \mathrm{MPa}$ at last. The suitable sludge content was determined to be $16 \%$ because too much sludge would lower the strength of briquette. Under the conditions of sludge content of $16 \%$ and forming pressure of $12 \mathrm{MPa}$, the cold compression strength of briquette reached maximum when the drying time was $12 \mathrm{~h}$, and then tended to be stable. Based on the results of single factor tests, the optimum conditions are as follows: $12 \mathrm{MPa}$ of forming pressure, $12 \mathrm{~h}$ of drying time, $16 \%$ of sludge content.

\section{Introduction}

Briquette binder plays an important role in the molding process of briquette and affects the quality of briquette[1-3]. Binder has important influence on strength, ash, water resistance, combustion efficiency, soot emission and price of briquette[4-5]. Therefore, the research and development of high efficiency binder with low price, high heat and cold strength and good water resistance has become a hot spot[6-8][1]. The lubricant sludge from wire drawing factories are very viscous because of its richness in organic matter, which provides application possibilities in briquette preparation as binder. In this paper, briquette was prepared from pulverized coal with this lubricant sludge as binder. The effects of lubricant sludge content, forming pressure and drying time on the strength of the briquette coal are investigated.

\section{Experimental materials, devices and equipment}

Experimental materials. The pulverized coal used in the experiment is taken from the existing samples in the laboratory. Industrial analyses are carried out to the air dried lubricant sludge and the results are as follows:

Table 1 The analyzed results of the pulverized coal and dried sludge

\begin{tabular}{|c|c|c|c|c|}
\hline \multirow{2}{*}{ Sample } & \multicolumn{4}{|c|}{ Industrial analysis } \\
\hline & $\mathrm{M}_{\mathrm{ad}}(\%)$ & $\mathrm{A}_{\mathrm{ad}}(\%)$ & $\mathrm{V}_{\mathrm{ad}}(\%)$ & $\mathrm{FC}_{\mathrm{ad}}(\%)$ \\
\hline Sludge & 4.46 & 36.95 & 52.70 & 5.89 \\
\hline
\end{tabular}

A certain amount of pulverized coal and lubricant sludge was mixed fully, and then the mixture was put into a mould and squeezing by a press machine. Finally, the briquette coal was prepared.

\section{Experimental results and discussion}

Determination of sludge viscosity. The viscosity of sludge was tested by rotating viscometer, and according to the experimental data of viscosity measurement, rheological characteristic curve is obtained as shown in Fig.1, the slope of which is the apparent viscosity of the fluid. From Fig. 1, it can be seen that the viscosity of the original sludge is $2.44 \mathrm{~Pa} \cdot \mathrm{s}$, which is 2.44 times that of water. The possibility of sludge as binder was demonstrated. 
Single factor test of briquette production from industrial sludge. The effects of forming pressure, sludge content and drying time on the strength of briquette were investigated. The determination of drop strength of briquette refers to MT/T 925-2004 standard of coal industry of the people's Republic of China for the determination of falling strength of industrial briquette. A certain amount of briquette samples are freely dropped from $2 \mathrm{~m}$ height to the steel plate. The drop strength of briquette is represented by the percentage of briquette mass larger than $13 \mathrm{~mm}$ in the sample mass of prototype coal, which is larger than $13 \mathrm{~mm}$ after the third fall.

Influence of sludge content on briquette strength. Under the conditions of forming pressure of 12 MPA and drying time of $24 \mathrm{~h}$, changing the sludge content and studying the effect of sludge content on the falling strength of briquette, the results are shown in Fig. 2. Fig. 2 indicates that when the sludge content is $10 \sim 16 \%$, the briquette strength increases gradually with the increase of sludge content. When the sludge content is $16 \%$, the briquette intensity reaches the maximum and then decreases. This is mainly due to the fact that both coal and sludge contain organic compounds, which have a strong affinity, and the binder can infiltrate coal well and even exist in the inner structure of coal. With the increase of sludge content, the increase of soakage ability plays a better role in the adhesion of briquette, which makes the strength of briquette increase. Continue to increase the sludge content, then the adhesion of sludge to pulverized coal is in a full state, and the moisture in briquette increases. The strength is decreasing gradually. Therefore, the suitable sludge content was determined to be $16 \%$.

Influence of forming pressure on briquette strength. Under the conditions of activated sludge content of $10 \%$ and drying time of 24 hours, the influence of forming pressure on the strength of briquette was studied by changing the forming pressure. The results are as shown in Fig. 3, which shows that with the increase of forming pressure, the falling strength of briquette increases first and then decreases. This is due to the smaller embedded force between pulverized coal particles and the smaller strength of briquette when the forming pressure is low. As the forming pressure increases, when the forming pressure is higher than a certain value, the pulverized coal will break up twice and produce a new surface under the condition of large bearing capacity. The original binder can not fully infiltrate it, which leads to the decrease of its strength. Therefore, the suitable forming pressure is determined to be $12 \mathrm{MPa}$.

Influence of drying time on strength of briquette. Under the conditions of sludge content of $16 \%$ and forming pressure of $12 \mathrm{MPa}$, the pulverized coal was molded by changing the drying time, and the effect of drying time on the falling strength of briquette was studied. The results are shown in Fig. 4. It can be seen from the diagram that when drying time is $12 \mathrm{~h}$, the strength of briquette cold pressing reaches the maximum and then tends to be stable. The results show that during the drying process not only the internal moisture in coal but also some combined water is removed. Molding moisture is an important factor affecting the quality index of briquette. In the process of forming, the material contains proper moisture, which can lubricate and moisturize the properties of binder, which is conducive to the tight accumulation of coal particles and the full diffusion of the binder. At the beginning of drying, there is more free water between pulverized coal particles and more moisture in sludge. The affinity of binder to coal is full, and the binder does not reach the best bonding property, which shows a slow rising trend..With the evaporation of water, the two can fully bond, and the strength of briquette increases sharply. After reaching a certain time, too much water is lost in coal samples and sludge, the moisture in briquette evaporates, and the moisture in sludge is also partially lost. The binder and coal begin to caking and even breaking, and the strength of briquette is gradually flattening or even decreasing. Therefore, the optimum drying time is $12 \mathrm{~h}$. 


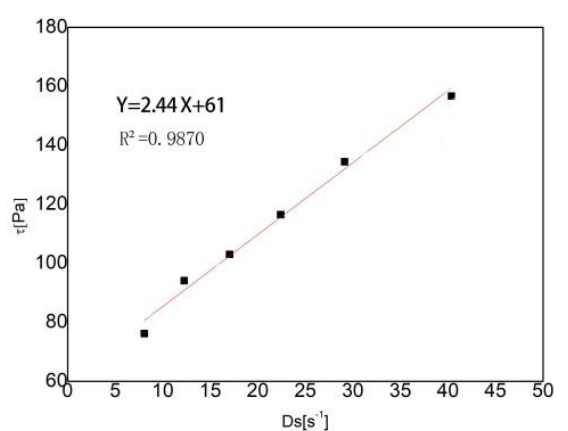

Fig. 1 Rheological curve of the lubricating oil sludge

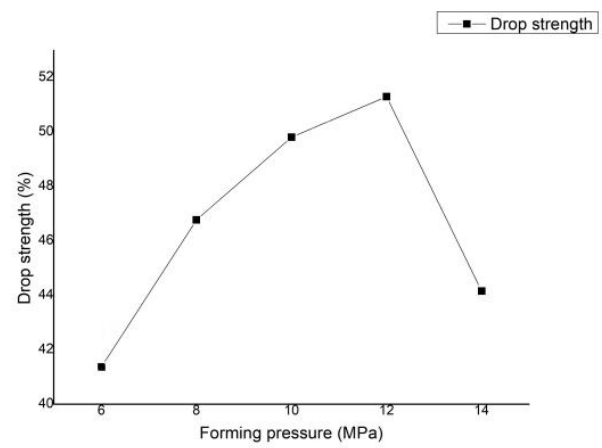

Fig. 3 Coal drop strength versus preparation pressure

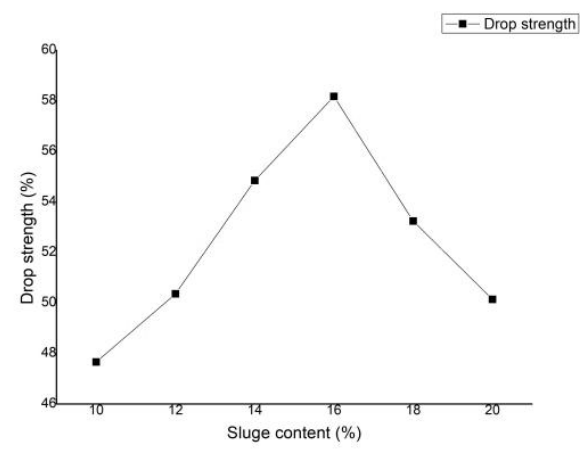

Fig. 2 Coal drop strength with sludge content of the briquette coal

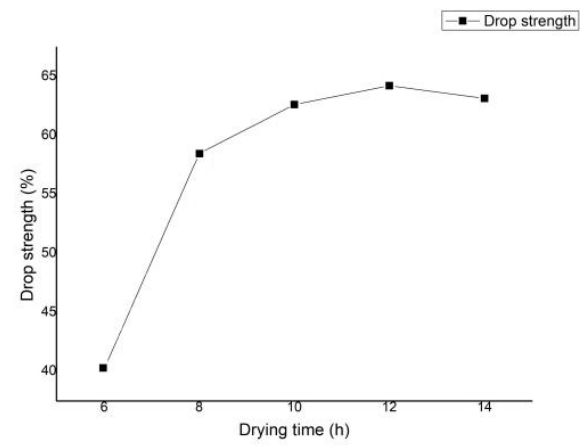

Fig. 4 Coal drop strength change curve with drying time

\section{Conclusions}

In this paper, it is found that the existing industrial sludge contains organic compounds with unsaturated fatty acids, and has good adhesive property, and can be used as binder to prepare briquette. The effects of sludge content, forming pressure and drying time on the strength of briquette were measured. The following conclusions are drawn:

(1) The viscosity of the original sludge is $2.44 \mathrm{~Pa} \cdot \mathrm{s}$, which is 2.44 times of that of water, and can be used as briquette binder.

(2) Under the conditions of activated sludge content of $10 \%$ and drying time of $24 \mathrm{~h}$, the suitable forming pressure is $12 \mathrm{MPA}$.

(3) Under the conditions of forming pressure $12 \mathrm{MPA}$, drying time $24 \mathrm{~h}$, the suitable sludge content is $16 \%$.

(4) Under the conditions of sludge content of $16 \%$ and forming pressure of $12 \mathrm{MPa}$, the optimum drying time is $12 \mathrm{~h}$.

Through the experimental results above, it is confirmed that the industrial sludge from this factory can be used as binder for briquette preparation, which not only saves the huge cost of treating industrial sludge, but also improves the utilization efficiency of sludge, and plays an important role in environmental protection.

\section{Acknowledgements}

This work was financially supported by Shandong Natural Science Foundation (No. ZR2018PEM003) and SDUST Research Fund (No. 2015RCJJ017) 


\section{References}

[1]Li Jian, YAN Long, KANG Yuhong, et al. Experimental study of briquette and formed coke preparation using activating sludge as hinder [J] .Clean Coal Technology,2017,23(1) :24-27.

[2] Chen Yanguang, Wang Qiqi ,Han Hongjing ,et al. Study on the Technology and performance Test of pressing briquette with calcium lignosulfonate as Binder $[\mathrm{J}]$.Energy Chemical Industry,2016(8).

[3]Zhang $\mathrm{X}, \mathrm{Xu} \mathrm{D}, \mathrm{Xu} \mathrm{Z}$, et al. The effect of different treatment conditions on biomass binder preparation for lignite briquette[J]. Fuel Processing Technology, 2001, 73(3):185-196.

[4] Deus J F D, Monteiro S N, D'Almeida J R M. Effect of drying, molding pressure, and strain rate on the flexural mechanical behavior of piassava (Attalea funifera Mart) fiber-polyester composites[J]. Polymer Testing, 2005, 24(6):750-755.

[5] Choi J P, Lyu H G, Lee W S, et al. Investigation of the rheological behavior of 316L stainless steel micro-nano powder feedstock for micro powder injection molding[J]. Powder Technology, 2014, 261(11):201-209.

[6] Yang Y B, Zheng Q X, Jiang T, et al. Study on Preparation of High Strength Formed Coke[C] International Congress on the Science and Technology of Ironmaking. 2009:402-406.

[7] Cui W, Li X, Zhou S, et al. Investigation on process parameters of electrospinning system through orthogonal experimental design [J]. Journal of Applied Polymer Science, 2007, 103(5):3105-3112.

[8] Y. Wang, X. Bai, Optical microscopy analysis of briquette binders, International Journal of Coal Science \& Technology, 1 (2014) 421-427.

[9] Lu G J, Cheng F Q. Preparation of Coal Briquette by Using Coal Waste and Coal Slurry[J]. Advanced Materials Research, 2012, 391-392:755-758.

[10]Cui P, Qu K L, Ling Q, et al. Effects of coal moisture control and coal briquette technology on structure and reactivity of cokes[J]. Coke \& Chemistry, 2015, 58(5):162-169.

[11]Plancher H, Agarwal P K, Severns R. Improving form coke briquette strength[J]. Fuel Processing Technology, 2002, 79(2):83-92.

[12]Zhang G, Sun Y, Xu Y. Review of briquette binders and briquetting mechanism[J]. Renewable \& Sustainable Energy Reviews, 2018, 82:477-487.

[13]Zhong Q, Yang Y, Li Q, et al. Coal tar pitch and molasses blended binder for production of formed coal briquettes from high volatile coal[J]. Fuel Processing Technology, 2017, 157:12-19.

[14]Yang Y, Wang Y, Li Q, et al. Investigation of Coal Tar Pitch Binder for the Production of Formed Coal Briquettes for COREX from High Volatile Coal Powder[M]// 7th International Symposium on High-Temperature Metallurgical Processing. Springer International Publishing, 2016:580-596. 